DEUIFD LIII / 2021, ss. 133-163.

\title{
Din Kültürü ve Ahlak Bilgisi Öğretmenlerinin Öğrencilere Problem Çözme Becerisi Kazandırma Yeterliği Üzerine Bir Alan Araştırması (Türkiye Örneği)
}

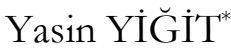

\begin{abstract}
ÖZ
Eğitim öğretim sürecinde öğrencilerin çeşitli bilgi, beceri, tutum ve davranışları kazanması amaçlanmaktadır. Türkiye'de beceri temelli öğretim yaklaşımın benimsenmesiyle birlikte Milli Eğitim Bakanlığ1, öğrencilerin üst düzey beceriler kazanmalarına daha çok önem vermeye başlamıştır. Öğretim sürecinde söz konusu olan becerilerden biri problem çözme becerisidir. Problem çözme becerisi, bir sorunla karşılaşan bireyin, kısa zamanda uyum sağlayabilmesi ve aklını kullanarak, planlı bir şekilde problemi ortadan kaldırabilmesine denir. Hayatın doğal bir parçası olarak her insan yaşam problemleriyle karşılaşmaktadır. $\mathrm{Bu}$ nedenle eğitimde öğrencilerin problem çözme becerisi kazanabilmesinin önemi büyüktür. Bu araştırmada Din Kültürü ve Ahlak Bilgisi öğretmenlerinin öğrencilere problem çözme becerisi kazandırma yeterlikleri ele alınmaktadır. Araştırma beceri temelli öğretim anlayışının din öğretiminde pratiğe yansımasına katkıda bulunması açısından önemlidir. Araştırmada 442 öğretmene Öğretmen Problem Çözme Becerisi Kazandirma Yeterliği Ölceğ uygulanmıştır. Elde edilen veriler SPSS programı aracılığyyla analiz edilmiştir. Araştırma sonucunda öğretmenlerin öğrencilere problem çözme becerisi kazandırma yeterliklerinin yüksek olduğu saptanmıştır. Araştırmada cinsiyet, görev bölgesi değişkenine göre anlamlı bir farkl1lık oluşmuş, mezuniyet durumu ve lisans diploma notu değişkenlerine göre anlamlı farklılaşma oluşmamıştır. Ayrıca ögretmenlerin beceriyi kazandırma yeterlik düzeyleriyle hizmet süreleri arasında pozitif yönlü, anlamlı bir ilişki tespit edilmiştir.
\end{abstract}

Dr. Öğr. Üyesi, Iğdır Üniversitesi, İlahiyat Fakültesi, Din Eğitimi Ana Bilim Dalı, Asst. Prof., Iğdır University, Faculty of Theology, Department of Religious Education, Iğdır, Turkey, yasnyigit@gmail.com, http://orcid.org/0000-0002-32545350

Makalenin Hakemlere Gönderiliş Tarihi : 15/04/2021

Makalenin Hakemlerden Geliș Tarihi : 29/05/2021 
Anahtar Kelimeler: Din Eğitimi, Beceri Temelli Öğretim, Öğretmen Yeterliği, Din Kültürü ve Ahlak Bilgisi, Problem Çözme Becerisi.

\title{
A Field Study on the Competency of Religious Culture and Ethics Teachers to Provide Students with Problem Solving Skills (Example of Turkey)
}

\begin{abstract}
It is aimed that students acquire various knowledge, skills, attitudes and behaviors during the education process. The Ministry of Education in conjunction with the adoption of skill-based teaching approach began to give more importance to gain the upper level of skills of students in Turkey. One of the skills involved in the teaching process is problem solving skill. Problem solving skill is the ability of an individual who encounters a problem to adapt in a short time and to eliminate the problem in a planned way by using his mind. As a natural part of life, every person faces life problems. For this reason, it is important for students to gain problem solving skills in education. In this study, the competence of Religious Culture and Moral Knowledge teachers to gain problem solving skills is discussed. Research is important in terms of contributing to the reflection of the skill-based teaching approach to practice in religious education. In this study, it was applied $A$ Scale of Competency of Teachers About Have Students Get the in Problem Solving Skills to the 442 teachers. The data obtained were analyzed through the SPSS program. As a result of the research, it has been determined that the teachers' competencies to have students get the problem solving skills are high. In the research, there was a significant difference in terms of gender, duty region variable, and there was no significant difference according to the variables of graduation status and undergraduate diploma grade. In addition, a positive and significant relationship was found between the teachers' competencies levels to have students get the problem solving skills and their service time.
\end{abstract}

Keywords: Religious Education, Skill-Based Teaching, Teacher Qualification, Religious Culture and Moral Knowledge, Problem Solving Skills. 


\section{GİRİŞ}

Eğitimin amacı bireylere bilișsel, duyușsal ve psikomotor alanlarla ilgili çeşitli bilgi, beceri, tutum ve davranışların kazandırılmasıdır. ${ }^{1}$ Eğitimden beklenen amaçlara ulaşılması için belirli bir zamanda ve mekânda, planlı ve programlı olarak yürütülen öğretim faaliyetlerinden yararlanılır. ${ }^{2} \mathrm{Bu}$ maksatla örgün öğretim kapsamında çeşitli derslere yer verilir. Bunlardan biri de Din Kültürü ve Ahlak Bilgisi (DKAB) dersidir.

DKAB, Türkiye'de Millî Eğitim Bakanllğ1 (MEB) bünyesindeki öğretim kurumlarında ilkokul 4. sınıftan başlayarak 12. sınıftan mezun oluncaya kadar Anadolu imam hatip liselerinde öğrenim görenler dışındaki tüm öğrencilerin haftada iki ders saati süreyle her yıl aldıkları zorunlu bir derstir. Dolayısıyla zorunlu eğitim sürecinin uzun bir bölümünde yer alan bu dersin nitelikli bireylerin yetiştirilmesinde önemli bir katkı sağlayabileceği söylenebilir. Ancak bu katkının sağlanabilmesi için öğretim sürecinin nitelikli bir şekilde yürütülmesi gerekir.

Bir dersin öğretiminin niteliği üzerinde temelde MEB, öğretmen, öğrenci ve veli gibi unsurların etkisi bulunabilmektedir. Ancak bunlar arasında en belirleyicinin, yani öğretim sürecinin baş aktörünün o dersin öğretmeni olduğu ifade edilebilir. ${ }^{3}$ Nurettin Topçu bu durumu "Muallim, ruhlar sanatkârıdır. Ruhların mürşidi, hayatın nâzımı ve istikbalin en emin kefili olacaktır. Farkında olsun olmasın, her ferdin şahsî tarihinde muallimin izleri bulunur. Devletleri ve medeniyetleri yapan da, y1kan da muallimleridir." ş şeklindeki sözleriyle manidar bir şekilde dile getirmiştir.

Bir öğretmenin mesleğinde yetkin olması doğru bilgi, doğru düşüncelere sahip ve doğru davranışlar sergileyen aydın bireylerin yetiştirebilmesi için önemli bir gereklilikken meslekî yetersizliği öğretim

\footnotetext{
Milli Eğitim Temel Kanunu (METK), Resmî Gazete 14574 (24 Haziran 1973), Kanun No. 1739, md. 2/3.

2 Remzi Y. Kıncal, Eğitim Bilimine Giriș, 2. Baskı (Ankara: Nobel Yayınları, 2009), 3.

3 Ayrıca bk. Lütfi Üredï - Yıldız Güven, "İlköğretim I. ve II. Kademe Öğretmenlerinin Öğretim Stili Tercihlerine Göre Öğretmenlik Mesleğine İlişkin Alg1larının İncelenmesi”, Marmara Üniversitesi Atatürk Eğitim Fakültesi Dergisi, 26 (2007): 164 .

4 Nurettin Topçu, Türkize'nin Maarif Davası, 8. Baskı (İstanbul: Dergah Yayınları, 2012), 67-69.
} 
sürecinin başarılı bir şekilde tamamlanamamasına neden olabilir. $\mathrm{Bu}$ durumdan eğitimin amaçlarına beklenen düzeyde ulaşılabilmesi için alanında profesyonel olan öğretmenlerin yetiştirilmesinin eğitimsel bir ihtiyaç olduğu anlaşılır. Bu ihtiyacın karşılanabilmesi için öğretmenlerin yeterlikleriyle ilgili eksikliklerin belirlenerek gerek lisans düzeyinde okutulan derslerle, gerekse de hizmet içi eğitim kurslarıyla telafi edilmeye çalışılması gerekir.

Türkiye'de benimsenen eğitim felsefesi incelendiğinde öğretimde beceri temelli yaklaşımın esas alındığı görülmektedir. ${ }^{5} \mathrm{Bu}$ anlayışa göre eğitim sürecinde öğrencilere kuru bilginin yaşamdan kopuk bir şekilde ezberletilmesi yerine yaşam boyu ihtiyaç duyulan temel ve üst düzey becerilerin kazandırılması hedeflenmektedir. Söz konusu becerilerden bazıları tüm derslerde, bazılarıssa sadece belli bir ya da birkaç derste öğrencilere kazandırılmaya çalış1lır.

Problem çözme becerisi, tüm derslerde kazandırılması hedeflenen ortak becerilerden biridir. MEB tarafından hazırlanan öğretim programlarında, bireyin kendisini rahatsız eden ve bu nedenle çözülmesi beklenen bir sorun karşısında doğru bir yaklaşım tarzını benimseyerek ve belli aşamaları izleyerek bir problemi çözebilme yeteneği anlamına gelen, problem çözme becerisi DKAB derslerinde öğrencilere kazandırılması amaçlanan üst düzey becerilerden biri olarak değerlendirilmektedir. ${ }^{6}$

Günümüzde bireyler hızlı toplumsal değişime uyum sağlamanın zorluklarına bağlı olarak yaşam sürecinde oldukça karmaşık problemlerle karşılaş1labilmektedir. Bundan ötürü günün insanının problem çözme becerisi edinmeye daha çok ihtiyacının bulunduğu söylenebilir. Dinî inançların bireyin tutum ve davranışlarına etkisi, yaşam problemlerinin psikolojik etkilerine karşı manevî güç kaynağı olarak ruhsal sağlık

\footnotetext{
MEB, Din Kültürü ve Ablak Bilgisi Dersi Öğretim Program (Illkokul 4 ve Ortaokul 5, 6, 7 ve 8. Simflar) (Ankara: MEB Yayınları, 2018), 9.

$6 \quad$ MEB, Din Kültürü ve Ablak Bilgisi Dersi Öğretim Programı (Ortaögretim 9, 10, 11 ve 12. Sinflar) (Ankara: MEB Yayınlar1, 2018), 8; MEB, Din Kültürü ve Ablak Bilgisi Dersi Ögretim Program (Illkokul 4 ve Ortaokul 5, 6, 7 ve 8. Simiflar), 8.
} 
açısından oynadığ1 rol ve problem çözmeye teşvik eden prensipleri düşünüldüğünde bu becerinin öğrencilere kazandırılmasinda din öğretiminin etkin bir rol icra edebileceği anlaşılmaktadır.

Din ögrretiminde problem çözme becerisi kazanma amacına ulaşılabilmesi, yapılan öğretim faaliyetlerinin niteliğine bağlıdır. Okullarda öğretim faaliyetleri öğretmenler tarafindan yürütülür. Bu nedenle öğretim sürecinde DKAB öğretmenlerinin söz konusu beceriyi öğrencilere kazandırma hususundaki yeterliklerinin yüksek düzeyde olması gerekir. Ancak DKAB öğretmenlerinin problem çözme becerisi kazandırma yeterliklerinin hangi düzeyde olduğu bilinmemektedir. Bu nedenle din öğretiminden sorumlu olan DKAB öğretmenlerinin söz konusu beceriyi öğrencilere kazandırma hususundaki yeterliklerinin tespit edilmesi araştırılmayı bekleyen bir meseledir.

Alan yazında bulunan konuyla ilgili çalısmalara bakıldığında bunlardan biri olan "Anadolu İmam Hatip Lisesi Meslek Derslerinin Problem Çözme Becerisi Kazandırması Açısından Fonksiyonelliği (Sivas İli Örneği)" adlı çalışmada Yasin Yiğit, meslek dersleri öğretmenlerinin öğrencilere problem çözme becerisi kazandırma yeterliklerini farklı değişkenler açısından ele alarak incelemiştir. "Din Kültürü ve Ahlak Bilgisi Derslerinde Probleme Dayalı Öğrenme" adlı kitapta Halit Ev, probleme dayalı öğrenmeyle ilgili teorik bilgilere yer verdikten sonra söz konusu yaklaşımın DKAB derslerinde uygulanması ile ilgili örneklere yer vermiştir." "Probleme Dayalı Öğrenme Yaklaşımının Kur'an Kursları Programındaki Dinî Bilgiler Dersinin Amaçlarının Gerçekleşmesine Etkisi” adlı araştırmada Rüveyda Durmuş, probleme dayalı öğrenmeyle ilgili yaptı̆̆1 deneysel çalışma ile yaklaşımın dinî bilgiler derslerindeki

Yasin Yiğit, Anadolu Imam Hatip Lisesi Meslek Derslerinin Problem Cözme Becerisi Kazandirması Açısından Fonksiyonelliği (Sivas İli Örneği) (Sivas: Sivas Cumhuriyet Üniversitesi, Sosyal Bilimler Enstitüsü, Doktora Tezi, 2019), 50-66.

8 bk. Yasin Yiğit, Anadolu Imam Hatip Lisesi Meslek Derslerinin Problem Cözme Becerisi Kazandirması Açısından Fonksiyonelliği (Sivas İli Örneği) (Sivas: Sivas Cumhuriyet Üniversitesi, Sosyal Bilimler Enstitüsü, Doktora Tezi, 2019).

9 bk. Halit Ev, Din Kültürü ve Ablak Bilgisi Derslerinde Probleme Dayal Öğrenme (Ankara: Nobel Yayınlar1, 2012). 
etkililiğini incelemiştir." "Sınıf Öğretmenlerinin Problem Çözme Becerisini Kazandırmaya Yönelik Öz-Yeterlikleri ile İlköğretim Öğrencilerinin Problem Çözme Becerileri Arasındaki İlişki” adlı çalışmada Kader Arkan, sınıf öğretmenlerinin öğrencilere problem çözme becerisi kazandırma yeterliklerini ele almıştır. ${ }^{11}$ Bu çalışmalardan sadece Yiğit'in ve Arkan'in çalışmaları öğretmenlerin problem çözme becerisi kazandırma yeterlikleriyle doğrudan ilgiliyken diğerlerinin beceriyle doğrudan bağlantısı bulunmamaktadır. Çalışmalar arasında DKAB öğretmenlerinin öğrencilere problem çözme becerisi kazandırabilme yeterlikleriyle ilgili herhangi bir müstakil çalısma bulunmamaktadır. Ayrıca yurt içi ve yurt dişı literatürde bu konuyla doğrudan ilgi kurulabilecek herhangi bir araştırmayla karşılaşılmamıştır. $\mathrm{Bu}$ araştırmada alan yazında söz konusu olan eksiklik giderilmeye çalışılmıştır.

\section{Problem, Amaç ve Hipotezler}

$\mathrm{Bu}$ araştırmada $\mathrm{DKAB}$ öğretmenlerinin öğrencilere problem çözme becerisi kazandırma yeterliklerinin ve söz konusu yeterlik düzeylerinin demografik değişkenlerin etkisine bağlı olarak farklılık gösterip göstermediğinin tespit edilmesi ele alınmıştır. $\mathrm{Bu}$ nedenle çalışmada öncelikle beceri temelli öğretim adı altında önemle üzerinde durulan becerilerden biri olan problem çözme becerisinin neliğinin ve din öğretimiyle ilişkisinin ifade edilmesi gerekmektedir.

Problem çözme becerisi problem, problem çözme ve beceri kavramlarından meydana gelen birleşik bir terimdir. Problem, sözlükte araştırilıp öğrenilmesi, düşünülüp çözümlenmesi ya da bir sonuca bağlanması gereken bir mesele, sıkıntı veren durum ve dert gibi anlamlara

10 bk. Ruveyda Durmuş, Probleme Dayal Öğrenme Yaklaşımının Kur'an Kurslar Programmdaki Dinı̂ Bilgiler Dersinin Amaçlarmm Gerçeklestirilmesine Katkııs (Ankara: Ankara Üniversitesi, Sosyal Bilimler Enstitüsü, Yüksek Lisans Tezi, 2014).

11 bk. Kader Arkan, Sinf Ögretmenlerinin Problem Cözme Becerisini Kąandırmaya Yönelik Öz-Yeterlikleri ile İlkögretim Ögrencilerinin Problem Cözme Becerileri Arasindaki İliski (İstanbul: Marmara Üniversitesi, Sosyal Bilimler Enstitüsü, Yüksek Lisans Tezi, 2011). 
gelmektedir. ${ }^{12}$ Araştırmacıların problem kavramı ile ilgili tanımlarına bakıldığındaysa problemin bireyin kendisi tarafindan araştırılıp çözülmesi, bertaraf edilmesi gereken bir sorun olarak algilanan, hedeflerine ulaşmasını engelleyen herhangi bir durum olarak ifade edildiği görülmektedir. ${ }^{13}$ Problem çözme, bireyin içsel ya da dişsal sebeplerle ortaya çıkan ve hayat sürecinde mutlu olmasinı engelleyen sorunları ortadan kaldırmak amacıyla yaptığı bilişsel, duyuşsal ya da davranışsal işlemlerin bütünüdür. ${ }^{14}$ Beceri ise bir şeyi bireysel yatkınlık ve öğrenmeye bağlı olarak makul bir süre içerisinde istenen nitelikte yapabilme, ustalık, maharet şeklinde tanımlanabilir. ${ }^{15}$

Problem, problem çözme ve beceri kavramlarının tanımlarında yer alan ortak noktalardan hareketle problem çözme becerisi, bireyin hayatta belirlediği hedeflerine ulaşmasını engelleyen, onu rahatsız eden sorunlar karşısında duruma en kısa sürede uyum sağlaması, sorumluluk almaktan kaçınmayarak bireysel ya da toplumsal problemlerin ortadan kaldırılması amacıyla bilişsel, duyuşsal veya davranışsal açıdan yapılması gereken her ne varsa başarllı bir şekilde yapabilmesini sağlayan üst düzey yaşam becerilerinden biri şeklinde tanımlanabilir.

12 Şükrü Haluk Akalın vd., Türk Dil Kurumu Türkese Sözlüke (Ankara: Türk Dil Kurumu, 2005), 1795.

13 Thomas J. D'Zurilla vd., "Social Problem Solving: Theory and Assessment", Social Problem Solving: Theory, Research and Training, ed. Edward C. Chang vd. (Washington: American Psychological Association, 2004), 12; Bülent Aksoy, "Problem Çözme Yönteminin Çevre Eğitiminde Uygulanması”, Pamukekale Üniversitesi Eğitim Fakültesi Dergisi 14 (2003), 83; Elif B. Türnüklü - Sibel Yeşildere, "Problem, Problem Çözme ve Eleştirel Düşünme", Gaz̧i Eğitim Fakültesi Dergisi (2005), 108; Clifford T. Morgan, Psikolojize Giriş, trc. Hüsnü Arıcı (Ankara: Hacettepe Üniversitesi Psikoloji Bölümü Yayınlar1, 2000), 149; P. Paul Heppner - Charles J. Krauskopf, “An Information-Processing Approach to Personal Problem Solving", The Counseling Psychologist 15 (1987), 376.

14 Heppner - Krauskopf, "An Information-Processing Approach to Personal Problem Solving", 375; Sadi Seferoğlu - Cenk Akbiyık, "Eleştirel Düşünme ve Öğretimi”, Hacettepe Üniversitesi Eguitim Fakültesi Dergisi 30 (2006), 194; Morgan, Psikolojiye Giris, 149; D'Zurilla vd., "Social Problem Solving: Theory and Assessment", 12; Thomas J. D'Zurilla vd., "Age and Gender Differences in Social Problem Solving Ability”, Personality and Individual Differences 25 (1998), 242.

15 Akalın vd., Türk Dil Kurumu Türkşe Sö̊lük, 230. 
Yaşam problemleri basit ya da karmaşık olmak üzere iki farklı şekilde ele alınabilir. Basit problemler bireyin gündelik olarak karşılaştığı, çözümü kolay olan, karmaş1k problemlerse bireyin alış1k olmadığı, yani çözümü konusunda yeteri kadar tecrübe edinmediği, birey üzerinde derin etkiler bırakma potansiyeline sahip olan sorunlardır. Birey, rutin olarak karşılaştığı basit sorunların çözümünü kolaylıkla bulabilir. Ancak karmaşı sorunlar önem derecesi ve boyutuna bağlı olarak bireyin hayatını altüst edebilir. Bu tür sorunların çözümünde bireyin öz güvenli olması, acele etmeden sorun hakkında enine boyuna düşünmesi ve planlı olarak belli aşamaları izlemesi gerekir. ${ }^{16}$

Araştırmacılara göre problem çözme, belli aşamaların takip edilmesiyle gerçekleşen bir süreçtir. Literatürde konuyla ilgili temelde birbirine oldukça benzeyen farklı problem çözme aşamalarıyla karşılaşmak mümkündür. Örneğin Clifford T. Morgan'a göre problem çözme sürecinde birbirini takip eden hazırlık, kuluçka, kavrayış ya da aydınlanma, değerlendirme ve düzeltme olmak üzere dört aşama bulunmaktadır. ${ }^{17}$ Bunun yanı sıra konu hakkında oldukça kabul gören bir diğer problem çözme aşamaları da John Dewey tarafından 1900'lü yıllarda ileri sürülmüştür. Ona göre problem çözme sürecinin beş aşaması bulunmaktadır. Bunlar: "Güçlülüğün farkına vararak problemi tanımlamak, ilgili bilgileri elde edip sınıflandırmak, çözüm için hipotezler belirlemek, daha önceden ortaya konan olası çözüm yollarını test etmek ve son olarak sonuçları doğrulamak ve değerlendirmektir." ${ }^{\text {"18 }}$

Problem durumunda doğru bir yaklaşım tarzının benimsenerek sistemli bir şekilde belli aşamaların takip edilmesi, karşılaşılan sorunların çok fazla hasara yol açmadan çözülmesini sağlayabilir. Böylece birey ve toplumun huzur ve refahını engelleyen durumların önüne geçilebilir. $\mathrm{Bu}$ nedenle mevcut bilgilerin devam edilen okuldan mezun olunmadan önce bile değişebildiği günümüz şartlarında eğitim öğretim sürecinde problem çözme becerisi kazanarak yeni durumlara makul bir süre içerisinde uyum

16 Nail Şahin vd., "Psychometric Properties of the Problem Solving Inventory in a Grup of Turkish University Students”, Cognitive Therapy Research 17/4 (1993), 392.

17 Morgan, Psikolojizy Giriş, 150.

18 John Dewey, How We Think, (Boston: D.C. Heath, 1910), 72. 
sağlayabilen, ${ }^{19}$ yeni sorunlara yeni çözüm yolları keşfetmeyi bilen gençlerin yetiştirilmesi önemlidir. Aynı durum genel eğitimin bir parçası olan din öğretimi için de geçerlidir.

Din öğretimi sürecinde bireyin din gerçekliği hakkında doğru bilgiler edinerek insana, düşünceye, hürriyete, ahlâkî olana ve kültürel mirasa sayg1 temelinde bilinçli bir tavır takınması amaçlanır. ${ }^{20}$ Din öğretiminden beklenen önemli bir amaçta düşünen, inancını aklıyla bütünleştiren, hayatın anlamını keşfeden, eleştiri cesareti olan ve yaptığı tercihlerin dayanaklarını bilen, böylece yaşam problemlerini çözme becerisi edinmiş bireyler yetiştirmektir. ${ }^{21}$

Öğrencilere problem çözme becerisinin kazandırılması örgün öğretim kapsamındaki farklı derslerin amaçları arasında bulunabilse de din öğretiminin bu husustaki yeri ayrıdır. Nitekim birey, hızlı sosyokültürel değişimin bir neticesi olarak yaşam sürecinde dinî hayatıyla ilgili yeni soru ve sorunlarla da yüzleşebilmektedir. Bireyin din öğretiminde problem çözme becerisi edinerek bu problemleri kendi başına çözebilmesi gerekir. Çünkü çağımızda kabul gören eğitim öğretim yaklaşımları da öğrencinin hazır bilgiyi ezberleyip depolaması yerine bilgiyi nerede ve nasıl bulup kullanacağına dair düşünme ve problem çözme faaliyetlerinin işlevsel hale getirilmesini sağlayan bir anlayışı benimsemektedir. ${ }^{22}$

Din öğretiminde problem çözme becerisinin edinilmesi bireyin sadece dinî hayatı için gerekli bir kazanım değildir. Çünkü birey ve toplumun ruh sağlığını koruyan ve geliştiren çok güçlü bir psikolojik unsur olarak din, ${ }^{23}$ bireyin hayatının bütününe etki edebilen bir

19 Ev, Din Kültürü ve Ablak Bilgisi Derslerinde Probleme Dayal Öğrenme, 27.

20 Mualla Selçuk, "Din Öğretiminin Kuramsal Temelleri (Zihin Gelişimi Açısından Bir Deneme)", Din Ë̆itimi Araştırmalar Dergisi, 4 (1997): 152.

21 Selçuk, "Din Öğretiminin Kuramsal Temelleri (Zihin Gelişimi Açısından Bir Deneme)",157-158.

22 Bilal Duman - Birsel Aybek, "Süreç Temelli ve Disiplinlerarası Öğretim Yaklaşımlarının Karşılaştırılması”, Muğla Üniversitesi Sosyal Bilimler Enstitüsü Dergisi, 11 (Aralik 2003): 2.

23 Ev, Din Kültürü ve Ablak Bilgisi Derslerinde Probleme Dayah Ögrenme, 29; Ayrica Bk. Randy Hebert vd., "Positive and Negative Religious Coping and Well-being in Women with Breast Cancer", Journal of Palliative Medicine 12/6 (2009), 537; Kenneth 
gerçekliktir. $\mathrm{Bu}$ nedenle batıl inançlardan arındırılmış dinî inançların mensuplarına telkin ve teşvik ettiği sorumluluk, çalışkanlık, sabır, şükür ve kanaat, aklı kullanma (tefekkür) gibi öğretilerinin bireyin yaşam sürecinde karşılaşabileceği her türlü problem durumunda doğru bir yaklaşım benimsemesini sağlamak ve güç yetiremediği sorunlar karşısında tevekkül bilinciyle hareket ederek, cesaret ve metanetle problemlerini çözebilmek bağlamında önemli bir katkısı vardır. ${ }^{24}$ Ayrıca dinin bencilliği reddeden, toplum yararına çalışmayı teşvik eden ilkeleri sayesinde mensuplarına kazandırdığı birlik, beraberlik, yardımlaşma ve dayanışma bilinciyle birbirine kenetlenen bireyler, sosyal sorunların çözülmesi için gönüllü olarak sorumluluk üstlenebilir. Bütün bunların problem çözme becerisiyle doğrudan ilgisi bulunmaktadır. Çünkü problem çözme becerisinin geliştirilmesi problem durumunda doğru bir tavır takınmayı gerektirir.

Problem durumunda doğru bir tavır takınarak yaşam sorunlarının çözülmesi, bireyin kendisini rahatsız eden problemlerinden kurtulmasını, böylece yaşam kalitesi ve memnuniyetinin artmasını sağlar. Bu sebeple öğrencilerin din öğretiminde problem çözme becerisi kazanma amacına erişim düzeyleri ile yaşam kaliteleri arasında pozitif yönde anlamlı bir ilişkinin olduğu söylenebilir.

Yaşam kalitesi ve memnuniyetinin artmasına vesile olabilen problem çözme becerisinin din eğitimi özelinde kazandiğı anlamı hakkındaki belirsizliğin giderilmesine katk1 sağlayan ve DKAB öğretmenlerinin söz konusu beceriyi öğrencilere kazandırma yeterliklerinin tespit edildiği bu araştırma, beceri temelli öğretim yaklaşımıla ilgili alandaki ilk çalışmalardan biridir.

I. Pargement vd., "Religious Coping Among The Religious: The Relationships Between Religious Coping and Well-being in a National Sample of Presbyterian Clergy, Elders, and Members", Journal for the Scientific Study of Religion 40/3 (2001), 497; Sema Eryücel, Yaşam Olaylar ve Dinî Başaçıma (Ankara: Ankara Üniversitesi, Sosyal Bilimler Enstitüsü, Doktora Tezi, 2013), 150; Şükran Çevik Demir, Ergenlerde Benlik Saygısı ve Dinî Başaçkma (Bursa: Uludağ Üniversitesi, Sosyal Bilimler Enstitüsü, Doktora Tezi, 2013), 208.

24 Yiğit, Anadolu Imam Hatip Lisesi Meslek Derslerinin Problem Çözme Becerisi Kazandırması Açısindan Fonksiyonelliği (Sivas İli Örneği), 197. 
Araştırmanın temel problemi, DKAB öğretmenlerinin öğrencilere problem çözme becerisi kazandırma yeterliklerinin ne düzeyde olduğudur. $\mathrm{Bu}$ problem çerçevesinde araştırmanın alt problemleri ise şunlardır:

1. DKAB öğretmenlerinin öğrencilere problem çözme becerisi kazandırma yeterlik düzeyleri doğru yaklaşımı benimsetme, ilgili yöntemi uygulama, motive etme açısından nedir?

2. DKAB öğretmenlerinin öğrencilere problem çözme becerisi kazandırma yeterlik düzeyleri cinsiyet, öğrenim durumu, lisans diploma notu ortalaması, görev bölgesi değişkenlerine göre farklılaşmakta mıdır?

3. DKAB öğretmenlerinin öğrencilere problem çözme becerisi kazandırma yeterlik düzeyleri ile hizmet süresi arasında anlamlı bir ilişki bulunmakta midir?

Çalışmada DKAB öğretmenlerinin öğrencilere problem çözme becerisi kazandırma yeterliğini tespit etmek ve öğretmenlerin yeterlik düzeyinin demografik değişkenlerin etkisine bağlı olarak farklılaşıp farklılaşmadığını belirlemek hedeflenmektedir. Bu amaç doğrultusunda araştırma kapsamında MEB'e bağlı öğretim kurumlarında halihazırda görev yapan bir grup öğretmenden elde edilen verilerden hareketle belirtilen alt problemlere cevap aranması amaçlanmışır.

Araştırmanın hipotezleri şu şekildedir:

1. DKAB öğretmenlerinin öğrencilere problem çözme becerisi kazandırma yeterlik düzeyleri doğru yaklaşımı benimsetme, ilgili yöntemi uygulama, motive etme açısından orta seviyededir.

2. DKAB öğretmenlerinin öğrencilere problem çözme becerisi kazandırma yeterlik düzeyleri cinsiyet, öğrenim durumu, lisans diploma notu ortalaması, görev bölgesi değişkenlerine göre anlamlı olarak farklılaşmaktadır.

3. DKAB öğretmenlerinin öğrencilere problem çözme becerisi kazandırma yeterlik düzeyleri ile hizmet süresi arasında pozitif yönde anlamlı bir ilisski bulunmaktadır. 


\section{Yöntem}

\subsection{Araştırmanın Modeli}

Araştırma nicel araştırma desenlerinden biri olan tarama modeline göre tasarlanmıştır. Tarama modelinde bir konu hakkındaki mevcut durumun tespit edilmesi amaciyla yürütülen araştırmalara betimsel tarama modeli, değişkenler arasında birlikte bir farklılaşmanın olup olmadığını ya da varsa bu değişimin hangi yönde ve hangi düzeyde bulunduğunu saptanmayı amaçlayan araştırmalara karşılasstırmal ilişkisel tarama modeli denilmektedir. ${ }^{25}$ Çalışma, DKAB öğretmenlerinin öğrencilere problem çözme becerisi kazandırma yeterliklerini betimlediği için betimsel tarama modeline, öğretmenlere uygulanan ölçekten alınan puan ortalamalarının çeşitli değişkenlere göre karşılaştırıldı̆̆ı için karşılaştırmalı iliskisel tarama modeline dayalıdır.

\subsection{Araştırmanın Evreni ve Örneklemi}

Araştırmanın evrenini 2020-2021 eğitim öğretim yllında MEB bünyesinde görev yapan DKAB öğretmenleri oluşturmaktadır. Araştırma kapsamında toplam 474 öğretmene ulaşılmış, ancak 32 kişinin eksik ya da özensiz cevap vermesinden dolay1 442 öğretmen örnekleme dahil edilmiştir. Örneklem Türkiye'nin farklı coğrafi bölgelerindeki okullarda görev yapan öğretmenler arasından gönüllülük esasına dayalı olarak rastgele seçilmiştir. Örnekleme dijital ortamlar üzerindeki öğretmen grupları aracıllğıyla ulaşılmıstır.

\subsection{Veri Toplama Araçları}

Araştırmada DKAB öğretmenlerine yönelik Kişisel Bilgi Formu ve Ögrretmen Problem Çözme Becerisi Kazandirma Yeterliği Ölçeği uygulanmıştır. Uygulanan kişisel bilgi formlarında öğretmenlerle ilgili bağımsız değişkenlere yer verilmiştir.

Yiğit tarafindan 2018 y1lında geliştirilen Öğretmen Problem Cö̋me Becerisi Kaz̧andırma Yeterlĭgi Ölçeği, beşli Likert tipinde hazırlanmıştır.

25 Niyazi Karasar, Bilimsel Araştırma Yöntemi: Kavramlar, Ilkeler, Teknikler, 32. Bask1 (Ankara: Nobel Yayınları, 2017), 107-119; Ayrica bk. W. Paul Vogt, Quantitative Research Methods for Professionals in Education and Other Fields (Columbus: Allyn \& Bacon, 2006), 41. 
Ölçekte toplamda 17 madde ve Doğru Yaklaşımı Benimsetme, İlgili Yöntemi Uygulama ve Motive Etme olmak üzere 3 alt boyut bulunmaktadır. Açımlayıcı faktör analizi sonuçlarına göre ölçeğin ortaya çıkan yapısının faktör yükleri, doğru yaklaşımı benimsetme alt boyutu için .415 ile .841 , ilgili yöntemi derste uygulama alt boyutu için .535 ile .896 , motive etme alt boyutu için .624 ile .850 arasında bulunmaktadır. Ölçeğin Cronbach Alfa iç tutarlılık katsayısı, doğru yaklaşımı benimsetme alt boyutu için .88, ilgili yöntemi derste uygulama alt boyutu için .82, motive etme alt boyutu için .78 , ölçeğin bütününün ise .91 'dir. Doğrulayıc1 faktör analizi sonuçlarından elde edilen modelin uyum indeksleri ise $\mathrm{x} 2 / \mathrm{sd}=1.508$, $\mathrm{SRMR}=.046, \quad \mathrm{RMSEA}=.045, \quad \mathrm{GFI}=.930, \quad \mathrm{RMR}=.029, \quad \mathrm{AGFI}=.904$, CFI $=.970, \quad$ IFI $=.970, \quad$ TLI $=.963$ şeklindedir. ${ }^{26} \quad \mathrm{Bu}$ araştırmadaysa Cronbach's Alpha kat sayısı doğru yaklaşımı benimsetme alt boyutu için .95 , ilgili yöntemi uygulama alt boyutu için .87 , motive etme alt boyutu için .90, ölçeğin bütünü için .96'dır. Ayrıca çalışmada KMO .962 ve Barlett testi $\chi^{2}$ değeri 6742,496 ( $\left.\mathrm{p}=.000\right)$ olarak hesaplanmıştır. Bu sonuçlar söz konusu olan ölçme aracının öğretmen problem çözme becerisi kazandırma yeterliliğini belirlemede geçerli ve güvenilir olduğunu göstermektedir.

\subsection{Verilerin Analizi}

Araştırmada verilerin analiz edilmesi için SPSS 23 istatistik paket programından yararlanılmıştır. Bu bağlamda öncelikli olarak verilerin normal dağılım gösterip göstermediği tespit etmek için Kolmogorov Smirnov normallik testi yapılmış, çarpıklık (skewness) ve basıklık (kurtosis) değerleri -1 ile +1 arasındaysa verilerin normal dağ $11 \mathrm{~m}$ gösterdiği kabul edilmiştir. ${ }^{27}$

Araştırmada katılımcıların ölçekten aldıkları ortalama puan $(\overline{\mathbf{X}})$ ve alınan puanların standart sapma (ss) değerleri hesaplanmıştır. Bu aşamada DKAB öğretmenlerinin problem çözme becerisi kazandırma yeterliliğine yönelik bulgular değerlendirilirken ölçekten alınan puan ortalamaları

26 Yasin Yiğit, "Öğretmen Problem Çözme Becerisi Kazandırma Yeterliği Ölçeğinin Geliştirilmesi: Geçerlik Güvenilirlik Çalışması”, Adiyaman Üniversitesi İslami İlimler Fakültesi İslami İlimler Arassttrmalar Dergisi, 4 (2018), 60-77.

27 Şener Büyüköztürk, Sosyal Bilimler İçin Veri Analizi El Kitabı (Ankara: Pegem A Yaymollk, 2012), 40. 
2.60-3.39 arasındaysa orta, 3.40-4.19 arasındaysa yüksek, 4.20-5.00 arasındaysa çok yüksek şeklinde yorumlanmıştır. ${ }^{28}$ Daha sonra ölçek puanlarının demografik değişkenlerin etkisiyle anlamlı düzeyde farklılık gösterip göstermediğini tespit etmek amacıyla kategori sayısına bağlı olarak Bağımsız Gruplar t-Testi veya Tek Yönlü Varyans Analizi (ANOVA) yapılmıştır. ANOVA sonuçlarından anlamlı farklılık elde edildiği durumlarda hangi post-hoc çoklu karşılaştırma tekniğinden faydalanılmasına karar verebilmek için Levene's testi yapılmış, bunun sonucunda grup dağılımlarının varyansları homojen olduğu için LSD testinin kullanılmasına karar verilmiştir. Değişkenler arasında anlamlı ilişkilerin bulunup bulunmadığ1 ise Pearson Momentler Çarpımı Korelasyon Katsayısı tekniğiyle hesaplanmış, analizlerde manidarlık düzeyi .05 olarak kabul edilmiştir. Sonuçlarla ilgili rapor hazırlanırken daha önceki araştırmalar da incelenerek karşılaştırmalar yapılmış, böylece araştırmalar arasındaki benzerlik ve farklılıkların ortaya konulması amaçlanmıştır.

\section{Bulgular}

Bu başlık altında çalısmada elde edilen bulgular tablolar halinde verilerek değerlendirilmiş ve sonuçlar ulaşılabilen benzer araştırmalarla karşılaştırılmıştır. Bu bağlamda katılımcılarla ilgili demografik bilgiler, ölçekten alınan puanların bağımsız değisskenlerin etkisine bağlı olarak farklılaşıp farklılaşmadığını gösteren t-testi ve ANOVA ile değişkenler arasındaki ilişkiye ait Pearson Momentler Çarpımı Korelasyon Analizi sonuçlarına burada yer verilmiştir.

\subsection{DKAB Öğretmenlerine Ait Demografik Bilgiler}

Araştırmaya katılan 442 katılımcıdan oluşan örneklem grubunun demografik özellikleri şu şekildedir:

Öğretmenlerin \%62.4'ünün kadın, \%37.6'sının erkek olduğu; $\% 81.7$ 'sinin lisans, \%17.2'sinin lisans üstü mezunu olduğu (\%1.1 kayıp veri); \%50.9'unun 0-5 y1l aras1, \%23.5'inin 6-10 yil aras1, \%15.6'sinin 1115 yll aras1, \%4.1'inin 16-20 y1l aras1, \%3.2'sinin 21-25 y1l aras1, \%2.7'sinin ise 26 yll ve üzeri görev yaptığ1; \%5.4'ünün lisans diploma not

28 Kazım Özdamar, Modern Bilimsel Araştırma Yöntemleri (Eskişehir: Kaan Kitabevi, 2003), 32 . 
ortalamasinın 50-65 arasinda, \%24.4'ünün 66-75 arasında, \%47.3’ünün 76-85 arasında, \%22.9'unun 86-100 arasinda olduğu; katılimciların \%8.4'ünün Doğu Anadolu, \%14.3'ünün Güneydoğu Anadolu, $\% 25.3$ 'ünün Marmara, \%23.8'inin İç Anadolu, \%9.5'inin Ege, \%10.2'sinin Akdeniz, \%8.6'sının da Karadeniz Bölgesinde görev yaptı̆̆1 saptanmiştır.

3.2. DKAB Öğretmenlerinin Problem Çözme Becerisi Kazandırma Yeterlik Düzeylerine İlişkin Betimsel Bulgular

Araştırmaya katılan öğretmenlerin Öğretmen Problem Çözฺme Becerisi Kazandırma Yeterliği Ölçĕ̋̆ nden aldıkları puanlara ilişkin betimsel veriler Tablo 1'de verilmiştir. 
Tablo 1. Öğretmen Problem Çözme Becerisi Kaz̧andırma Yeterliği Ölçeği ve Alt Boyutlarn ile İlgili Betimsel Bulgular

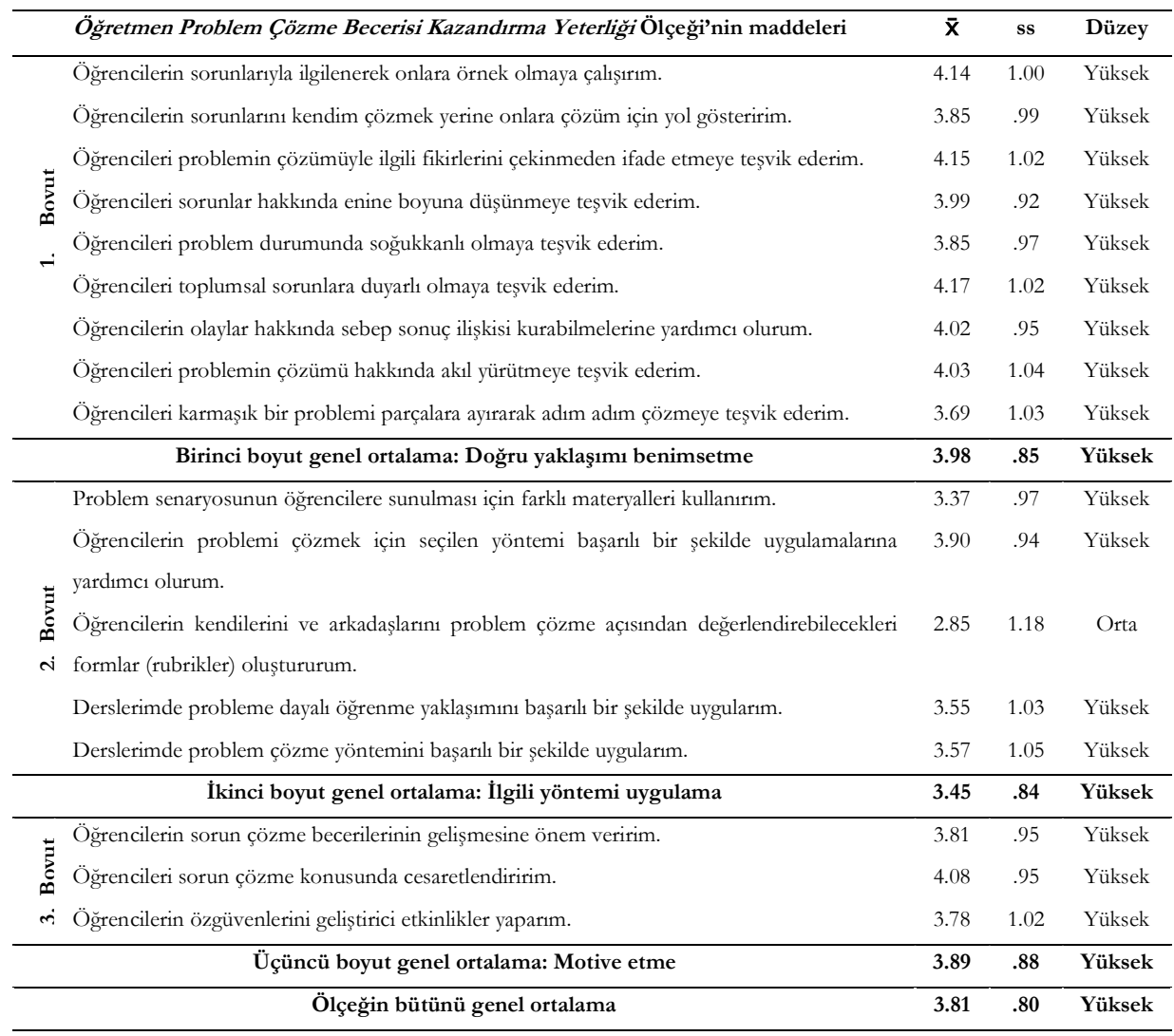

Tablo 1'de görüldüğü gibi DKAB öğretmenlerinin “Öğretmen

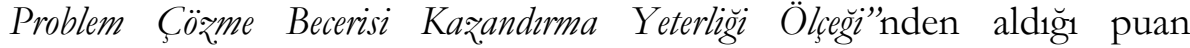
ortalamas1 ( $\overline{\mathbf{X}}=3.81)$ yüksek düzeydedir. Ölçeğin alt boyutları incelendiğinde birinci boyut olan "Doğru Yaklaşım Benimsetme" alt boyutundan alınan puan ortalaması $(\overline{\mathbf{X}}=3.98)$ yüksek, ikinci boyut olan "İgili Yöntemi Uygulama" alt boyutundan alınan puan ortalaması $(\overline{\mathbf{X}}=3.45)$ yüksek, üçüncü boyut olan "Motive Etme" alt boyutundan alınan puan ortalaması ( $\overline{\mathbf{X}}=3.89)$ yüksek düzeyde olduğu görülmektedir.

Çalışmadan elde edilen bulgular incelendiğinde "DKAB öğretmenlerinin öğrencilere problem çözme becerisi kazandırma yeterlik düzeyleri doğru yaklaşımı benimsetme, ilgili yöntemi uygulama, motive 
etme açısından orta seviyededir." şeklindeki hipotezin doğrulanmadığı anlaşılmaktadır. Ancak gerek ölçek maddelerine, gerekse de alt boyutlara ya da ölçeğin bütününe bakıldığında herhangi bir ortalamanın çok yüksek düzeyde olmaması göze çarpmaktadır. Bunun nedeni problem çözme becerisi kazandırmanın alan bilgisinden çok meslekî becerilerle ilgili olması ve birçoğu ilahiyat fakültesinden mezun olan DKAB ögrretmenlerinin pedagojik formasyon derslerini yeterli oranda almamaları olabilir.

Konuyla ilgili olarak literatüre bakıldığında öğretmenlerin öğrencilere problem çözme becerisi kazandırmalarıyla ilgili yeterliklerinin incelendiği çalışmaların din eğitimi alanında olduğu gibi genel eğitimde de oldukça sınırlı sayıda olduğu görülmüştür. Karşılaştırma yapılabilecek az sayıdaki araştırmalardan biri olan Yiğit tarafından hazırlanan ve bu araştırmada yararlanılan ölçeğin ilk kullanıldığı çalışmada Anadolu imam hatip lisesi (AİHL) meslek dersleri öğretmenlerinin öğrencilere problem çözme becerisi kazandırma yeterliklerinin ölçeğin bütünü ve alt boyutları açısından yüksek düzeyde olduğu tespit edilmiştir. ${ }^{29}$ Konu ile ilgili olarak Mustafa Mücahit tarafından yapılan bir diğer çalışmada Sivas ilinde görev yapan AİHL meslek dersleri öğretmenlerine öğrencilerin sorunlarının çözümüne yardımc1 olmaları bakımından yeterli olup olmadıkları sorulmuş, öğretmenlerin \%76,6'sıdan yeterliyim cevabı alınmıştır. ${ }^{30}$ Söz konusu olan her iki çalışmadaki bulgular bu araştırmayı destekler niteliktedir.

\subsection{Bağımsız Değişkenlere İlişkin Bulgular}

Bağımsız değişkenlere ilişkin bulgularla ilgili veriler Tablo 2, Tablo 3, Tablo 4, Tablo 5 ve Tablo 6'da verilmiştir.

29 Yiğit, Anadolu Imam Hatip Lisesi Meslek Derslerinin Problem Çözme Becerisi Kazandırması Açısindan Fonksiyonelliği (Sivas İli Örneği), 133.

30 Mustafa Mücahit, Imam Hatip Lisesi Meslek Dersleri Ögrretiminde Ögrretmenin Rolü (Sivas Ili Örneği) (Sivas: Cumhuriyet Üniversitesi, Sosyal Bilimler Enstitüsü, Doktora Tezi , 2016), 220. 
Tablo 2. DKAB Ögrretmenlerinin Problem Cö̃me Becerisi Kazandirma Yeterlik. Düzeylerinin Cinsiyete Göre t-Testi Sonuclar

\begin{tabular}{lccccccc}
\hline & & & & \multicolumn{5}{c}{ t-testi } \\
\cline { 7 - 9 } Cinsiyet & $\mathbf{N}$ & $\overline{\mathbf{X}}$ & ss & $\mathbf{t}$ & $\mathbf{s d}$ & $\mathbf{F}$ & $\mathbf{p}$ \\
\hline Kadın & 276 & 3.95 & .54 & & & & \\
Erkek & 166 & 4.10 & .48 & -2.751 & 398 & 1.091 & .006 \\
\hline
\end{tabular}

Tablo 2'de DKAB öğretmenlerinin öğretmen problem çözme becerisi kazandırma yeterliği ölçeğinden elde edilen sonuçları cinsiyet değişkenine göre karşılaştırılmıştır. Bu sonuçlar incelendiğinde kadın öğretmenlerin puan ortalamasinın $(\overline{\mathbf{X}}=3.95)$, erkek öğretmenlerin puan ortalamasının ( $\overline{\mathbf{X}}=4.10)$ olduğu görülmektedir. Ölçekten alınan puanlar arasında anlamlı farklı1ık bulunup bulunmadığı bağımsız iki örneklem ttestiyle analiz edilmiştir. Analiz sonuçlarına göre kadın ve erkek öğretmenlerin ölçekten aldıkları puan ortalamaları arasındaki farkın ( $\mathrm{t}=$ 2.751, sd=398, $\mathrm{p}=0.006<0.05) \mathrm{p}<0.05$ manidarlık düzeyinde anlamlı bulunduğu saptanmıştır.

Analiz sonuçlarından hareketle "DKAB öğretmenlerinin öğrencilere problem çözme becerisi kazandırma yeterlik düzeyleri cinsiyet değişkenine göre anlamlı olarak farklılaşmaktadır." şeklindeki hipotezin doğrulandığı anlaşılmaktadır. Bu durumun nedeni erkek öğretmenlerin derslerinde sınıf yönetimi hususunda daha başarılı olmaları ve kendilerini daha öz güvenli hissetmeleri ya da kadın öğretmenlerin ev, çocuk ve iş sarmalında daha çok sorumluluk almaları dolayısıyla performanslarında düşüşün yaşanması olabilir.

Konuyla ilgili olarak daha önce yapılan araştırmalar incelendiğinde Yiğit tarafindan yapılan çalışmada AİHL meslek dersi öğretmenlerinin öğrencilere problem çözme becerisi kazandırma yeterlik düzeylerinin cinsiyete göre anlamlı olarak farklılaşmadığı görülmektedir. ${ }^{31}$ Aynı şekilde Arıkan tarafindan hazırlanan çalışmada da sınıf öğretmenlerinin öğrencilere problem çözme becerisi kazandırma

31 Yiğit, Anadolu Imam Hatip Lisesi Meslek Derslerinin Problem Çözme Becerisi Kazandirması Açsindan Fonksiyonelliği (Sivas İli Örneği), 134. 
yeterliklerinin cinsiyete göre anlamlı olarak farklılaşmadığ1 bulgusuna ulaşılmıştır. ${ }^{32} \mathrm{Bu}$ bulgular çalışmamızla örtüşmemektedir.

Tablo 3. DKAB Ögretmenlerinin Problem Çözme Becerisi Kazandorma Yeterlik Düreylerinin Mezuniyet Durumuna Göre t-Testi Sonuclar

\begin{tabular}{lccccccc}
\hline & & & \multicolumn{5}{c}{ t-testi } \\
\cline { 8 - 9 } Mezuniyet & $\mathbf{N}$ & $\overline{\mathbf{X}}$ & $\mathbf{s s}$ & $\mathbf{t}$ & $\mathbf{s d}$ & $\mathbf{F}$ & $\mathbf{p}$ \\
\hline Lisans & 361 & 4.00 & .53 & & & & \\
Lisans Üstü & 76 & 4.05 & .50 & -.861 & 105.127 & .013 & .391 \\
\hline
\end{tabular}

Tablo 3’te DKAB öğretmenlerinin öğretmen problem çözme becerisi kazandırma yeterliği ölçeğinden elde edilen sonuçları mezuniyet durumuna göre karşılaştırılmıştır. Bu sonuçlar incelendiğinde lisans mezunu olan öğretmenlerin puan ortalamasının $(\overline{\mathrm{X}}=4.00)$, lisans üstü mezunu olan öğretmenlerin puan ortalamasının $(\overline{\mathbf{X}}=4.05)$ olduğu görülmektedir. Ölçekten alınan puanlar arasında anlamlı farklılık bulunup bulunmadığı bağımsız iki örneklem t-testiyle analiz edilmiştir. Analiz sonuçlarına göre lisans ya da lisans üstü mezunu olan öğretmenlerin ölçekten aldıkları puan ortalamaları arasındaki farkın ( $\mathrm{t}=-.861$, $\mathrm{sd}=105.127, \mathrm{p}=0.391>0.05) \quad \mathrm{p}<0.05$ manidarlı düzeyinde anlaml bulunmadığı saptanmıştır.

Analiz sonuçlarından hareketle "DKAB öğretmenlerinin öğrencilere problem çözme becerisi kazandırma yeterlik düzeyleri mezuniyet durumu değişkenine göre anlamlı olarak farklılaşmaktadır." şeklindeki hipotezin doğrulanmadığı anlaşılmaktadır. Bu durumun nedeni $\mathrm{DKAB}$ öğretmenlerinin lisans üstü eğitim sürecinde meslekî bilgi ve becerilerini geliştirebilecekleri alanlardan ziyade ilahiyat alan bilgisine yönelik alanlara yönelmeleri olabilir. Çünkü ilahiyat bünyesinde din eğitimi dışındaki bilim dalları ile pedagojik formasyon eğitimi arasında doğrudan bir ilişki kurulamamaktadır.

Konuyla ilgili olarak Yiğit tarafindan yapılan araştırma incelendiğinde AİHL meslek dersi öğretmenlerinin öğrencilere problem

32 Arkan, Sinıf Öğretmenlerinin Problem Çözme Becerisini Kazandırmaya Yönelik ÖzYeterlikleri ile İlköğretim Öğrencilerinin Problem Cö̧̈me Becerileri Arasındaki Iliş̧ki, 66. 
çözme becerisi kazandırma yeterlik düzeylerinin mezuniyete göre anlamlı olarak farklılaşmadığ 1 görülmektedir. ${ }^{33}$ Söz konusu araştırma çalışmamızı destekler niteliktedir. Arıkan tarafindan hazırlanan çalışmadaysa sınıf öğretmenlerinin öğrencilere problem çözme becerisi kazandırma yeterlikleri mezuniyet durumuna göre anlamlı olarak farklılaşmaktadır. Çalışmaya göre bu farklılaşma lisans üstü eğitim alan öğretmenlerin lehinedir. ${ }^{34} \mathrm{Bu}$ araştırma bulguları çalışmamızla örtüşmemektedir. Bunun nedeni sınıf öğretmenlerinin eğitim fakültelerinde öğrenim görmeleri dolayısıyla lisans üstü öğrenim sürecinde meslekî bilgi ve becerilerini geliştirebilecekleri alanlara daha yüksek oranda yönelmiş olmaları olabilir.

Tablo 4. DKAB Öğretmenlerinin Problem Çӧzme Becerisi Kazandirma Yeterlik. Düzeylerinin Lisans Diploma Not Ortalamasina Göre ANOV A Testi Sonuçlar

\begin{tabular}{|c|c|c|c|c|c|c|c|c|c|c|}
\hline \multicolumn{5}{|c|}{$f, \bar{x}$ ve ss Değerleri } & \multicolumn{6}{|c|}{ ANOVA Sonuçları } \\
\hline Not Ort. & $\mathrm{N}$ & $\bar{x}$ & ss & Var. K & $\mathrm{KT}$ & $\mathrm{Sd}$ & $\mathrm{KO}$ & $\mathrm{F}$ & $\mathrm{p}$ & LSD \\
\hline $1-50-65$ aras 1 & 24 & 3.93 & .62 & \multirow{4}{*}{$\begin{array}{l}\text { G. } \\
\text { Arası } \\
\text { G. İçi } \\
\text { Toplam }\end{array}$} & .294 & 3 & .098 & .352 & .787 & \multirow{4}{*}{$\begin{array}{c}\text { Anlaml } \\
\text { fark } \\
\text { yok }\end{array}$} \\
\hline $2-66-75$ aras1 & 108 & 4.02 & .51 & & 110.269 & 396 & .278 & & & \\
\hline $3-76-85$ arasi & 209 & 4.02 & .50 & & 110.563 & 399 & & & & \\
\hline $\begin{array}{ll}4-86 & \text { ve } \\
\text { yukarisı } & \end{array}$ & 101 & 3.97 & .55 & & & & & & & \\
\hline
\end{tabular}

Tablo 4'te DKAB öğretmenlerinin öğrencilere problem çözme becerisi kazandırma yeterliği ölçeğinden elde edilen sonuçlar lisans diploma not ortalaması değişkenine göre karşılaştırılmıştır. Bu sonuçlar incelendiğinde lisans diploma not ortalaması 50-65 arasinda olan öğretmenlerin ölçek puanlarının ortalaması $(\overline{\mathbf{X}}=3.93)$, 66-75 arasında olanların ( $\overline{\mathbf{X}}=4.02), 76-85$ arasinda olanların $(\overline{\mathbf{X}}=4.02), 86$ ve üzerinde olanların $(\overline{\mathbf{X}}=3.97)$ olduğu görülmektedir.

33 Yiğit, Anadolu Imam Hatip Lisesi Meslek Derslerinin Problem Cözme Becerisi Kazandorması Açısından Fonksiyonelliği (Sivas İli Örneği) , 137.

34 Arkan, Sinf Ögrretmenlerinin Problem Cözme Becerisini Kazandirmaya Yönelik ÖzYeterlikleri ile İlkögretim Ögrencilerinin Problem Çözme Becerileri Arasindaki Ilişki, 68-69. 
Çalışmada ölçek puanları arasındaki farkın anlamlı olup olmadığını saptamak için tek yönlü varyans analizi (ANOVA) yapılmıştır. Analiz sonuçlarına göre öğretmen problem çözme becerisi kazandırma yeterliği ölçeğinden alınan puan ortalamalarının lisans diploma not ortalaması değişkenine göre $\mathrm{p}<0.05$ manidarlık düzeyinde istatistiksel olarak anlamlı farklılık bulunmadığ saptanmıştır. $(\mathrm{F}=352 ; \mathrm{p}=$ $0.787>0.05)$.

Analiz sonuçları, lisans diploma not ortalaması değişkenine göre öğretmenlerin öğrencilere problem çözme becerisi kazandırma yeterlik düzeylerinin anlamlı olarak farklılaşmadığını ortaya koymaktadır. Bu bulgulardan "DKAB öğretmenlerinin öğrencilere problem çözme becerisi kazandırma yeterlik düzeyleri lisans diploma notu ortalaması değişkenine göre anlamlı olarak farklılaşmaktadır." şeklindeki hipotezin doğrulanmadığ1 anlaşılmaktadır. Bunun nedeni ilahiyat fakültelerinde okutulan pedagojik formasyon derslerinin sayı, ders saati ve kredilerinin düşük olması dolayısıyla genel akademik başarı ortalamasına etkisinin az olması olabilir. Konuyla ilgili olarak Yiğit tarafından yapılan çalışmada AİHL meslek dersi öğretmenlerinin öğrencilere problem çözme becerisi kazandırma yeterlik düzeylerinde öğrenim sürecinde oldukça verimli ya da çok verimli derecede pedagojik formasyon dersleri alan öğretmenlerin lehine anlamlı farklılığın oluşmasi ${ }^{35}$ da bu tezi destekler niteliktedir.

35 Yiğit, Anadolu Imam Hatip Lisesi Meslek Derslerinin Problem Çözme Becerisi Kazandrması Açısından Fonksiyonelliği (Sivas İli Örneği) , 139. 
Tablo 5. DKAB Ö̆gretmenlerinin Problem Ç̈̈zme Becerisi Kazandirma Yeterlik Düzeylerinin Görev Yapulan Bölgeye Göre ANOV A Testi Sonuçlar

\begin{tabular}{|c|c|c|c|c|c|c|c|c|c|c|}
\hline \multicolumn{4}{|c|}{$f, \bar{x}$ ve ss Değerleri } & \multicolumn{6}{|c|}{ ANOVA Sonuçları } & \multirow[b]{2}{*}{ LSD } \\
\hline Görev Yeri & $\mathrm{N}$ & $\overline{\mathrm{x}}$ & Ss & Var. K & $\mathrm{KT}$ & $\mathrm{Sd}$ & $\mathrm{KO}$ & $\mathrm{F}$ & $\mathrm{p}$ & \\
\hline 1-Doğu & 37 & 3.92 & .42 & \multirow{8}{*}{$\begin{array}{l}\text { G. } \\
\text { Arası } \\
\text { G. İçi } \\
\text { Toplam }\end{array}$} & 4.582 & 6 & .764 & \multirow[t]{8}{*}{2.832} & \multirow[t]{8}{*}{.010} & \multirow{4}{*}{$\begin{array}{l}6>1 \\
6>2 \\
6>3 \\
6>4\end{array}$} \\
\hline Anadolu & & & & & 105.981 & 393 & .270 & & & \\
\hline $\begin{array}{l}\text { 2-Güneydoğu } \\
\text { Anadolu }\end{array}$ & 63 & 3.92 & .54 & & 110.563 & 399 & & & & \\
\hline $\begin{array}{l}\text { Anadoiu } \\
\text { 3-Marmara }\end{array}$ & 112 & 3.93 & .57 & & & & & & & \\
\hline 4-İç Anadolu & 105 & 4.04 & .52 & & & & & & & \multirow{2}{*}{$\begin{array}{l}6>5 \\
7>3\end{array}$} \\
\hline 5-Ege & 42 & 3.97 & .50 & & & & & & & \\
\hline 6-Akdeniz & 45 & 4.26 & .45 & & & & & & & \\
\hline 7-Karadeniz & 38 & 4.14 & .43 & & & & & & & \\
\hline
\end{tabular}

Tablo 5'te DKAB öğretmenlerinin öğrencilere problem çözme becerisi kazandırma yeterliği ölçeğinden elde edilen sonuçlar görev yapılan bölge değişkenine göre karşılaştırılmıştır. Bu sonuçlar incelendiğinde Doğu Anadolu'da görev yapan öğretmenlerin ölçek puanlarının ortalaması ( $\overline{\mathbf{X}}=3.92), \quad$ Güneydoğu Anadolu'da görev yapanların ( $\overline{\mathbf{X}}=3.92)$, Marmara'da görev yapanların $(\overline{\mathbf{X}}=3.93)$, İç Anadolu'da görev yapanların $(\overline{\mathbf{X}}=4.04)$, Ege'de görev yapanların $(\overline{\mathbf{X}}=3.97)$, Akdeniz'de görev yapanların $(\overline{\mathbf{X}}=4.26)$, Karadeniz'de görev yapanların $(\overline{\mathbf{X}}=4.14)$ olduğu görülmektedir.

Çalışmada ölçek puanları arasında anlamlı bir farklılık bulunup bulunmadığını tespit etmek amaciyla tek yönlü varyans analizi (ANOVA) yapılmıştır. Analiz sonuçlarına göre öğretmen problem çözme becerisi kazandırma yeterliği ölçeğinden alınan puan ortalamalarının görev yapılan bölge değişkenine göre $\mathrm{p}<0.05$ manidarlık düzeyinde istatistiksel olarak anlamlı farklılık bulunduğu saptanmıştır $(\mathrm{F}=2.832 ; \mathrm{p}=0.010<0.05)$. Bunun üzerine tespit edilen anlamlı farklllı̆̆ın hangi gruplar arasında oluştuğunu belirlemek amaciyla tamamlayıcı post-hoc analizine başvurulmuştur. Bu amaçla öncelikle hangi post-hoc çoklu karşılaştırma tekniğinden faydalanılacağına karar vermek için Levene's testi yapılmıştır. $\mathrm{Bu}$ testten grup dağılımlarının varyanslarının homojen olduğu 
anlaşılmıştır ( $\mathrm{LF}=1.015 ; \mathrm{p}=0.415>0.05)$. Daha sonra yapılan post-hoc LSD testinden elde edilen sonuçlara göre Akdeniz Bölgesi’nde görev yapan öğretmenlerle Doğu Anadolu, Güneydoğu Anadolu, Marmara, İç Anadolu ve Ege bölgelerinde görev yapanlar arasinda Akdeniz Bölgesi'nde görev yapanların lehine; Karadeniz Bölgesi'nde görev yapanlarla Marmara'da görev yapanlar arasında Karadeniz bölgesinde görev yapanların lehine anlamlı bir farklılığın bulunduğu tespit edilmiştir. Diğer gruplar arasında anlamlı bir farklılık oluşmamıştır.

Analiz sonuçlarından hareketle "DKAB öğretmenlerinin öğrencilere problem çözme becerisi kazandırma yeterlik düzeyleri görev yapılan bölge değişkenine göre anlamlı olarak farklılaşmaktadır." şeklindeki hipotezin doğrulandığ anlaşılmaktadır. Bu durumun nedeni tatil bölgeleri olmaları dolayısıyla daha çok tercih edilme olasılı̆̆ bulunan Akdeniz ve Karadeniz Bölgeleri'nde görevli olan öğretmenlerin MEB tarafından meslekî anlamda daha yeterli olanları yordadığı düşünülerek yapılan bir sınav olan Kamu Personeli Seçme Sınavı puanlarının daha yüksek olmas1, dolayısıyla eğitim bilimleri ile ilgili bilgi ve becerilerinin daha üst düzeyde olması olabilir.

Tablo 6. DKAB Öğretmenlerinin Problem Cözme Becerisi Kazandırma Yeterlik Düzeyleri ile Hizmet Süresi Arasindaki Ilişsiye Ait Pearson Momentler Carpim Korelasyon Analizi

\begin{tabular}{lcc}
\hline & \multicolumn{2}{c}{ Hizmet Süresi } \\
\cline { 2 - 3 } Öğretmen Problem Çözme Becerisi & $\mathrm{r}$ & $.123^{*}$ \\
Kazandıra Yeterliği Ölçeği Puanı & $\mathrm{p}$ & .014 \\
& $\mathrm{~N}$ & 442 \\
\hline
\end{tabular}

* Korelasyon 0.05 düzeyinde anlamlıdır.

Tablo 6 incelendiğinde DKAB öğretmenlerinin öğretmen problem çözme becerisi kazandırma yeterliği ölçeğinden aldıkları puan ortalamaları ile hizmet süreleri arasında anlamlı bir ilişkinin bulunup bulunmadığını tespit etmek için yapılan Pearson Momentler Çarpımı Korelasyon Analizi sonucunda değişkenler arasında istatistiki olarak pozitif yönlü anlamlı bir ilişki bulunduğu görülmektedir $(\mathrm{r}=0.123$; $\mathrm{p}=0.014<0.05 ; \mathrm{N}=442)$. Buna göre $\mathrm{DKAB}$ öğretmenlerinin hizmet süreleri arttkça öğretmen problem çözme becerisi kazandırma yeterliği 
ölçeğinden aldıkları puan da artmakta veya değişkenlerden biri azalırken diğeri de aynı şekilde azalmaktadır.

Analiz sonuçları, DKAB öğretmenlerinin öğretmen problem çözme becerisi kazandırma yeterliği ölçeğinden aldıkları puan ortalamaları ile hizmet süreleri arasında pozitif yönde anlamlı bir ilişkinin bulunduğunu ortaya koymaktadır. Bu bulgulardan hareketle "DKAB öğretmenlerinin öğrencilere problem çözme becerisi kazandırma yeterlik düzeyleri ile hizmet süresi arasında pozitif yönde anlamlı bir ilişki bulunmaktadır.” şeklindeki hipotezin doğrulandığı anlaşılmaktadır. Bu durumun nedeni göreve yeni başlayan öğretmenlerin meslekleri ile ilgili tecrübelerinin kısıtlılığından dolayı konuyla ilgili olarak öz güvenlerinin azalması olabilir.

Konuyla ilgili olarak Yiğit tarafindan yapılan araştırma incelendiğinde AİHL meslek dersi öğretmenlerinin öğrencilere problem çözme becerisi kazandırma yeterlik düzeylerinin hizmet süresi değişkenine göre anlamlı olarak farklılaşmadığı görülmektedir. ${ }^{36}$ Arkan tarafından yürütülen araştırma da bu bulguyu desteklemektedir. ${ }^{37}$ Söz konusu araştırmalar bu çalışmayla örtüşmemektedir.

\section{SONUÇLAR VE ÖNERİLER}

Günümüz toplumlarında sosyokültürel ve teknolojik anlamda süratli bir değişim görülmektedir. Bu durum çağın insanının ve toplumlarının her geçen gün kendisini geliştirerek bir adım öteye taşımasını gerekli kılmaktadır. Söz konusu değişim eğitim öğretim yaklaşımlarına da yansıdığı için gerçek hayatta kullanılmayan kuru bilgilerin ezberlenmesi yerine öğrenilenlerin anlamlandırılarak pratiğe yansıtılabilmesi amacıyla MEB tarafindan öğretim programları beceri temelli olarak yapılandırılmıştır.

Beceri temelli öğretim yaklaşımının bir gereği olarak DKAB derslerinde öğrencilere kazandırılması amaçlanan becerilerden biri olan problem çözme becerisi, genel anlamda karşılaşılan yaşam problemlerinin

36 Yiğit, Anadolu Imam Hatip Lisesi Meslek Derslerinin Problem Cözme Becerisi Kazandorması Açsindan Fonksiyonelliği (Sivas İli Örneği), 139.

37 Arkan, Sinf Ögretmenlerinin Problem Cözme Becerisini Kazandirmaya Yönelik ÖzYeterlikleri ile Illkögretim Öğrencilerinin Problem Ç̨̈̈me Becerileri Arasindaki Ilisklei, 67. 
ortadan kaldırılabilmesi için en doğru yolun bulunabilmesi ve belli aşamaların takip edilerek çözümün uygulanabilmesi anlamında kullanılmaktadır. Din öğretimi bağlamında ele alındığındaysa problem çözme becerisi, özelde bireyin din ve ahlakla ilgili karşılaşttğ1 soru ve sorunlarını kendi başına çözebilme yetisi anlamında kullanılmaktadır. Bunun yanı sıra yaşam problemleriyle karşılaşan bireylerin gerektiğinde dinî başa çıkma stratejilerine de başvurarak metanetini koruması, dinden öğrendiği prensipleri problem çözme aşamalarına entegre ederek problemleri çözme hususunda cesaretli olması, sorumluluktan kaçmaması ve böylece sorunlarını bertaraf edebilmesi şeklinde ifade edilebilir.

Bireyin hedeflerine ulaşmasını engelleyen sorunlarını ortadan kaldırarak yaşam kalitesinin ve memnuniyetinin artmasına katkı sağlayan problem çözme becerisinin din öğretimi aracilığıla öğrencilere kazandırılmasında DKAB öğretmenlerinin önemli bir rolü bulunur. Nitekim öğretmenler geleceğin mimarı olan çocukların ve gençlerin dimağlarında derin izler bırakabilen, ayrıca onları ruhsal, bedensel, ahlakî ve akademik anlamda yetiştiren sanatkârlardır.

$\mathrm{Bu}$ araştırmada Türkiye'de $\mathrm{DKAB}$ öğretmenlerinin çağımız insanı için önemli bir gereksinim olarak görülen problem çözme becerisini öğrencilere kazandırma hususundaki yeterlik düzeylerinin tespit edilmesi ve demografik değişkenlerin etkisine bağlı olarak sonuçların ne şekilde farklılaştığını saptamak amaçlanmıştır.

Araştırmanın sonucunda DKAB öğretmenlerinin öğrencilere problem çözme becerisi kazandırma yeterlik düzeylerinin yüksek düzeyde $(\overline{\mathbf{X}}=3.81)$ olduğu, bu sonuçların cinsiyet değişkenine göre erkek öğretmenlerin lehine, görev yeri değişkenine göre Akdeniz Bölgesi’nde görev yapan öğretmenlerle Doğu Anadolu, Güneydoğu Anadolu, Marmara, İç Anadolu ve Ege Bölgeleri'nde görev yapanlar arasında Akdeniz Bölgesi'nde görev yapanların lehine; Karadeniz'de görev yapanlarla Marmara'da görev yapanlar arasında Karadeniz Bölgesi'nde görev yapanların lehine anlamlı bir farklılığın bulunduğu, mezuniyet durumu ve lisans diploma notu değişkenlerine göre anlamlı farklılaşmanın bulunmadığı, ayrıca DKAB öğretmenlerinin problem çözme becerisi kazandırma yeterlik düzeyleriyle hizmet süreleri arasında pozitif yönlü ve anlamlı bir ilişkinin var olduğu saptanmıştır. 
Araştırmanın sonuçlarından hareket ederek konuya ilgi duyan araştırmacıların, DKAB öğretmeni yetiştiren kurumların, MEB'in, öğretmenlerin ve ilgili diğer kurum ya da kuruluşların DKAB öğretmenlerinin öğrencilere problem çözme becerisi kazandırma yeterlik düzeylerinin yüksek düzeyden çok yüksek seviyeye çıkarılması için şu önerileri dikkate alması gerektiği ifade edilebilir:

1. DKAB öğretmenlerinin öğrencilere problem çözme becerisi kazandırması uzmanlık gerektiren bir iştir. Öğretmenlerin bu alandaki yeterliklerinin geliştirilmesi için öncelikle becerinin din öğretimi özelinde kazandığ1 anlamlarla ilgili daha detaylı müstakil araştırmalar yapılarak alandaki belirsizlik giderilmeli ve DKAB öğretmenlerine hizmet içi eğitim verilmelidir. Bu bağlamda konuyla ilgili alt yap1 eksikliğinin giderilmesi amacıyla karşılaşılan yaşam problemlerinin yaşa bağlı olarak değişkenlik göstermesi dolayısıyla gelişim dönemlerinin her birine özgü olarak din bilimlerinin ve eğitim bilimlerinin verilerinin sentezlendiği yeni araştırmalar yapılabilir. Ayrıca içeriğinde problem çözme becerisinin din eğitimi alanına özgü olarak kazandığı anlamları barındıran maddelerin yer aldığ1 yeni bir ölçek geliştirilerek öğretmenlerin yeterliklerinin tespit edilmesini amaçlayan farklı çalışmalar yürütülebilir.

2. Öğrencilere problem çözme becerisi kazandırabilmeleri için DKAB öğretmenlerinin güncel yaşam problemleriyle ilgili farkındalık bilincine sahip olmaları gerekir. Bu da iyi bir genel kültür ve alan bilgisi gerektirir. Bunun yanı sıra öğretmenlerin derslerinde probleme dayalı öğrenme ve problem çözme yöntemlerini uygulayabilecek nitelikte meslekî formasyona sahip olmaları gerekir. $\mathrm{Bu}$ nedenle DKAB öğretmenleri lisans düzeyinde nitelikli bir eğitim sürecinden geçirilerek yetiştirilmeli, alanlarıyla ilgili güncel gelişmeleri takip etmeleri ve lisans üstü eğitime yönelmeleri için teşvik edilmelidir. Ayrıca öğretmenlerin bilgi ve becerilerini geliştirmeleri için MEB tarafından açılan hizmet içi eğitim kurslarından faydalanılmalıdır. Bunun için seminer dönemlerinde öğretmenlere yönelik konferanslar düzenlenebilir ya da öğretmenler EBA üzerinden yürütülen uzaktan eğitim kurslarına katılmaları için teşvik edilebilir. Öte yandan yaşam problemlerinin çözülmesinde dinî başa çıkma stratejilerinden ve manevî güç kaynağ1 olan değerlerden yararlanılmas1, problem çözme becerisini kazanma ve öğrencilere kazandırma açısından etkili olabileceği için DKAB öğretmenlerinin 
manevi danışmanlık ve rehberlik alanında lisans üstü eğitim almaları da konuyla ilgili bilgi ve becerilerinin geliştirilmesine katkı sağlayabilir.

3. DKAB öğretmenlerinden manevî danışmanlık ve rehberlik alanında lisans üstü eğitim alanlar ve ilgili hizmet içi eğitim kurslarına katılanlar sertifikalandırılabilir ve okul rehber öğretmeni ile işbirliği halinde öğrencilerin manevî-dinî sorunlarıyla bireysel olarak ilgilenmeleri sağlanabilir. Bunun için öğretmenlere haftada birkaç ders saati süreyle görev verilebilir.

4. DKAB derslerinde bilimsel problem çözme adımlarının öğrencilere müstakil bir konu olarak öğretilmesi uygun görülmeyebilir. Ancak en azından yaşamda karşılaşılabilen güncel sorunlardan yararlanılarak oluşturulan problem senaryoları kullanılarak dersin konularıyla ilgili probleme dayalı ögrenme yaklaşımı ve problem çözme yöntemine uygun etkinlikler aracıllğılla bu sürecin öğrencilere benimsetilmesi sağlanabilir. $\mathrm{Bu}$ anlamda mevcut ders kitaplarının fonksiyonelliği ilgili kurum ve kuruluşlarca yeniden gözden geçirilmeli ve söz konusu etkinliklere de yer verilmesi için gerekli değişiklikler yapılmalıdır. Nitekim kitaplarda bilgi yükleyen uzun metinlerin yerine öz bilgi ve bol etkinliğe yer verilmesi günümüz eğitim anlayışı için daha uygun olacaktır.

5. DKAB ders kitaplarının içeriğinde öğrencilerin güncel problemler hakkındaki farkındalı̆̆ının artırılmasına gereken önem verilmeli, öğretmenler de güncel olayları takip ederek bu olayları yeri geldiğinde dersin müfredatıyla ilişkilendirmeli ve probleme dayalı öğrenme yaklaşımına uygun olarak problem senaryolarına dönüştürmelidir. Daha sonra bu sorunların çözülmesine yönelik öneriler bulmaları amaciyla öğrencilere bireysel olarak ya da grupla yapabilecekleri araştırma görevleri verilmelidir.

6. Öğretmenlerin genel tutum ve davranışlarında öğrencilere model olması gerektiği gibi bir problemle karşılaşmaları durumunda da metanetli davranmaları, aklını kullanarak ve İslâm medeniyetinin birikiminden faydalanarak bilimsel sorun çözme sürecini takip etmeleri gerekmektedir. Bunun için DKAB öğretmenlerinin İslâm dininde teşvik edilen tefekkür, sorumluluk, çalışkanlık, tevekkül, sabır, şükür ve kanaat gibi problem çözme becerisi ile ilişkilendirilebilecek öğretileri davranış haline getirerek öğrencilere model olmaları önemli katkılar sağlayabilir. 
Öte yandan aileyle işbirliği yapılarak ebeveynlerin de problem durumunda doğru bir model olması teşvik edilebilir.

7. Öğretmenlerin mevcut problemlerin çözümünü ezberleyen bireyler yerine yeni problemlere yeni çözüm yolları bulabilecek nitelikte bireyler yetiştirmeyi prensip olarak benimsemeleri, öğretim faaliyetlerinde s1k sık probleme dayalı öğrenme yaklaşımı ve problem çözme yöntemlerinden yararlanarak bunu pratiğe yansitmaları gerekir. 


\section{KAYNAKÇA}

Akalın, Şükrü Haluk vd. Türk Dil Kurumu Türkşe Sǫ̈lük. Ankara: Türk Dil Kurumu, 2005.

Aksoy, Bülent. "Problem Çözme Yönteminin Çevre Eğitiminde Uygulanmas1". Pamukkale Üniversitesi Eğitim Fakültesi Dergisi 14 (2003), 83-98.

Arkan, Kader. Simf Ögrretmenlerinin Problem Cöżme Becerisini Kazandırmaya Yönelik Ö₹-Yeterlikleri ile Illkögretim Ögrrencilerinin Problem Cö̈me Becerileri Arasindaki İlişki. İstanbul: Marmara Üniversitesi, Sosyal Bilimler Enstitüsü, Yüksek Lisans Tezi, 2011.

Büyüköztürk, Şener. Sosyal Bilimler İ̧in Veri Analiz̧i El Kitabı. Ankara: Pegem A Yaymalik, 2012.

Çevik Demir, Şükran. Ergenlerde Benlik Saygısı ve Dinî Başa Çıma. Doktora Tezi. Bursa: Uludağ Üniversitesi, Sosyal Bilimler Enstitüsü, Doktora Tezi, 2013.

Dewey, John. How We Think. Boston: D.C. Heath, 1910.

Duman, Bilal - Aybek, Birsel. "Süreç Temelli ve Disiplinlerarası Öğretim Yaklaşımlarının Karşılaştırılması”. Muğla Üniversitesi Sosyal Bilimler Enstitüsü Dergisi 11 (01 Aralık 2003), 1-12.

Durmuş, Ruveyda. Probleme Dayalı Öğrenme Yaklaşmmnn Kur'an Kurslar Programindaki Dinî Bilgiler Dersinin Amaçlarmmn Gerçekleștirilmesine Katkıss. Ankara: Ankara Üniversitesi, Sosyal Bilimler Enstitüsü, Yüksek Lisans Tezi, 2014.

D'Zurilla, Thomas J. vd. "Age and Gender Differences in Social Problem Solving Ability". Personality and Individual Differences 25 (1998), 241-252.

D'Zurilla, Thomas J. vd. "Social Problem Solving: Theory and Assessment". Social Problem Solving: Theory, Research and Training. Ed. Edward C. Chang vd. 3-27. Washington: American Psychological Association, 2004.

Eryücel, Sema. Yaşam Olaylar ve Dinî Başą̧ıkma. Ankara: Ankara Üniversitesi, Sosyal Bilimler Enstitüsü, Doktora Tezi, 2013. 
Ev, Halit. Din Kültürü ve Ablak Bilgisi Derslerinde Probleme Dayah Ögrenme. Ankara: Nobel Yayın, 2012.

Hebert, Randy vd. "Positive and Negative Religious Coping and Wellbeing in Women With Breast Cancer". Journal of Palliative Medicine 12/6 (2009), 537-545.

Heppner, P. Paul - Krauskopf, Charles J.. "An Information-Processing Approach to Personal Problem Solving". The Counseling Psychologist 15 (1987), 371-447.

Karasar, Niyazi. Bilimsel Arastırma Yöntemi: Kavramlar, İlkeler, Teknikler. Ankara: Nobel Yayınları, 2017.

Kıncal, Remzi Y. Eğitim Bilimine Giriş. 2. Baskı. Ankara: Nobel Yayınları, 2009.

MEB. Din Kültürü ve Ablak Bilgisi Dersi Ögretim Program (Illkokul 4 ve Ortaokul 5, 6, 7 ve 8. Simiflar). Ankara: MEB Yayınlar1, 2018.

MEB. Din Kültürü ve Ablak. Bilgisi Dersi Öğretim Program (Ortä̈gretim 9, 10, 11 ve 12. Simflar). Ankara: MEB Yayınları, 2018.

METK, Milli Eğitim Temel Kanunu. Resmî Gažete 14574 (2 Haziran 1973). $\quad$ Erişim $19 \quad 2021$. https://www.mevzuat.gov.tr/MevzuatMetin/1.5.1739.pdf

Morgan, Clifford T.. Psikolojizye Giriș. çev. Hüsnü Arıcı. Ankara: Hacettepe Üniversitesi Psikoloji Bölümü Yayınları, 2000.

Mücahit, Mustafa. Imam Hatip Lisesi Meslek Dersleri Ögrretiminde Ögretmenin Rolü (Sivas İli Ömeği). Sivas: Cumhuriyet Üniversitesi, Sosyal Bilimler Enstitüsü, Doktora Tezi, 2016.

Özdamar, Kazım. Modern Bilimsel Araștırma Yöntemleri. Eskişehir: Kaan Kitabevi, 2003.

Pargament, Kenneth I. vd. "Religious Coping Among the Religious : The Relationships Between Religious Coping and Well-being in a National Sample of Presbyterian Clergy, Elders, and Members". Journal for the Scientific Study of Religion 40/3 (2001), 497-513.

Seferoğlu, Sadi - Akbıyık, Cenk. "Eleştirel Düşünme ve Öğretimi”. Hacettepe Üniversitesi Eğitim Fakültesi Dergisi 30 (2006), 193-200. 
Selçuk, Mualla. "Din Öğretiminin Kuramsal Temelleri (Zihin Gelişimi Açısından Bir Deneme)". Din Eğitimi Arastırmalar Dergisi. 4 (1997): 145-158.

Şahin, Nail vd. "Psychometric Properties of the Problem Solving Inventory in a Group of Turkish University Students". Cognitive Therapy Research 17/4 (1993), 379-396.

Topçu, Nurettin. Türkiye'nin Maarif Davası. İstanbul: Dergah Yayınları, 8. Bask1, 2012.

Türnüklü, Elif B. - Yeşildere, Sibel. "Problem, Problem Çözme ve Eleştirel Düşünme”. Gaz̧i Eğitim Fakültesi Dergisi (2005), 107-123.

Üredi,, Lütfi - Güven, Yildız. "İlköğretim I. ve II. Kademe Öğretmenlerinin Öğretim Stili Tercihlerine Göre Öğretmenlik Mesleğine İlişkin Algılarının İncelenmesi”. Marmara Üniversitesi Atatürk Eğitim Fakültesi Dergisi 26 (2007), 163-179.

Vogt, W. Paul. Quantitative Research Methods for Professionals in Education and Other Fields. Columbus: Allyn \& Bacon, 2006.

Yiğit, Yasin. Anadolu Imam Hatip Lisesi Meslek Derslerinin Problem Cözme Becerisi Kazandirmasi Açısindan Fonksiyonelliŭi (Sivas İi Örneği). Sivas: Sivas Cumhuriyet Üniversitesi, Sosyal Bilimler Enstitüsü, Doktora Tezi, 2019.

Yiğit, Yasin. "Öğretmen Problem Çözme Becerisi Kazandırma Yeterliği Ölçeğinin Geliştirilmesi: Geçerlik Güvenilirlik Çalışması”. Adiyaman Üniversitesi İslami İlimler Fakültesi İslami İlimler Arasttrmaları Dergisi 4 (2018), 60-77. 